\title{
Serum levels of cytokines in infants treated with Conbercept for retinopathy of prematurity
}

\section{Yong Cheng}

Peking University People's Hospital

\section{Xuemei Zhu}

Peking University People's Hospital

\section{Dandan Linghu}

Peking University People's Hospital

\section{Zhongxu Jia}

Peking University People's Hospital

\section{Yongsheng Xu}

Peking University Third Hospital

Jianhong Liang ( $\nabla$ drliangjianhong@126.com )

Peking University People's Hospital

\section{Research article}

Keywords: cytokine, retinopathy of prematurity, vascular endothelia growth factor, conbercept, intravitreal injection, inflammatory factor

Posted Date: April 17th, 2020

DOI: https://doi.org/10.21203/rs.2.17703/v2

License: (c) (i) This work is licensed under a Creative Commons Attribution 4.0 International License. Read Full License

Version of Record: A version of this preprint was published at Scientific Reports on July 29th, 2020. See the published version at https://doi.org/10.1038/s41598-020-69684-7. 
The authors have withdrawn this preprint from Research Square 